\title{
The Research on Enterprise Innovation and Upgrading
}

\author{
Jie $L u^{1, a^{*}}$ and Yuanjian Qin ${ }^{2, b}$ \\ 1, 2Wuhan University of Technology, Hongshan District, Wuhan, Hubei, China \\ a1097043020@qq.com, bY QJHB@163.com \\ *The Corresponding author
}

Keywords: Enterprise; Innovation and upgrading; Influencing factors; Performance form

\begin{abstract}
Based on the systematic analysis and in-depth study, this paper puts forward the concept connotation of enterprise innovation and upgrading, and summarizes the performance form of enterprise innovation and upgrading, and explores the factors that affect the innovation and upgrading of enterprises on the basis of the research on enterprise innovation, upgrading and transformation and upgrading. Finally, constructing the relevant theoretical model of enterprise innovation and upgrading.
\end{abstract}

\section{Introduction}

Enterprises go on to advance in the reform, seek to develop in the innovation. In the process of innovation and upgrading of enterprises, some enterprises have passed the test of the market, they are success in innovation and upgrading; some enterprises were eliminated; some are struggling. What factors led to a part of the enterprises gorgeous turned, gain the success of innovation and upgrading; and another part of the enterprises did not keep up with the pace of the times, and finally be eliminated? Understand what is the innovation and upgrading of enterprises, which factors affect the enterprise's innovation and upgrading, it has theoretical and practical significance.

\section{Research on Enterprise Innovation and Upgrading}

Domestic and foreign scholars did not define what is the enterprise innovation and upgrading, foreign only defines the enterprise innovation and enterprise upgrading, the domestic only defines the enterprise innovation, upgrading, transformation and upgrading.

Schumpeter first introduced the concept of "innovation" in 1912, and since then, innovation has been paid more and more attention by academics and practitioners [1]. Enterprise innovation is the creation and innovation of enterprises in all aspects of thinking, products, services, technology, organization and system, management, marketing and culture, so that enterprises can make full use of their own resources, optimize the allocation of resources to meet the changing needs of the market. In 1999, Gereffi from the perspective of the global value chain, first proposed the content of enterprise upgrading, and identified it as a process to improve the profitability of the enterprise [2]. Humphrey and Schmitz argue that enterprise upgrading is an enterprise promotes high value-added activities by enhancing its competitiveness, such as getting advanced technology [3].

Domestic and foreign scholars have more research on the transformation and upgrading of enterprises, they mainly focused on the connotation, classification, motivation, path, performance, measurement and so on. Shengsheng Chen and other scholars explain the transformation and upgrading of enterprises from two aspects, one is transformation, the second is upgrading [4]. Changwen Zhao and others think that: enterprise transformation and upgrading is the process of enterprise to obtain high-tech level, improve the value, the process can be achieved by management change, organizational restructure and development model change [5]. Bo Zhang believes that the transformation and upgrading of enterprises is a strategic response to environmental change, which means that in order to adapt to the rapid changes in the external environment or internal conditions, maintain the survival and development of enterprises, enterprises need to change their own strategies, create new competitive advantage through use of potential opportunities [6]. 
Based on the deep research on enterprise innovation, enterprise upgrading and enterprise transformation and upgrading, this paper defines the enterprise innovation and upgrading: Enterprise innovation and upgrading is the enterprise continue to promote the relevant innovation activities and change activities from the enterprise management, technology, products, marketing and other aspects in order to seek the sustainable long-term development in the fierce market competition and changing internal and external environment, then enterprises can gain the core competitiveness which is not easily imitated and replaced, and finally improve the value of enterprises through innovation and integration of their own resources and capacity.

\section{The Performance Form of Enterprise Innovation and Upgrading}

What will change after enterprises innovation and upgrading? (See Table 1 for details)

Table 1 The performance form of enterprise innovation and upgrading

\begin{tabular}{|c|c|c|c|}
\hline $\begin{array}{l}\text { Level } \\
\text { indicators }\end{array}$ & Secondary indicators & $\begin{array}{c}\text { Level } \\
\text { indicators }\end{array}$ & Secondary indicators \\
\hline \multirow{4}{*}{$\begin{array}{c}\text { Enterprise } \\
\text { strategic } \\
\text { ability }\end{array}$} & Enterprise transformation & \multirow{4}{*}{$\begin{array}{c}\text { Product } \\
\text { innovation } \\
\text { ability }\end{array}$} & Product function is enhanced \\
\hline & Enterprise transition & & Product added value is increased \\
\hline & Enterprise shift & & development cycle is shortened \\
\hline & Others & & Product diversification \\
\hline \multirow{4}{*}{$\begin{array}{c}\text { Market } \\
\text { developm } \\
\text { e-nt } \\
\text { ability }\end{array}$} & Enter the new market & \multirow{4}{*}{$\begin{array}{l}\text { Enterprise } \\
\text { managem- } \\
\text { ent ability }\end{array}$} & Unique corporate culture \\
\hline & $\begin{array}{l}\text { Original market share is } \\
\text { increased }\end{array}$ & & Advanced management methods \\
\hline & Brand influence is increased & & $\begin{array}{l}\text { Reasonable organizational } \\
\text { structure }\end{array}$ \\
\hline & $\begin{array}{l}\text { Way of operation is more } \\
\text { efficient }\end{array}$ & & Perfect system mechanism \\
\hline
\end{tabular}

Enterprise strategic ability is the core competitiveness of enterprises which concretely express in the strategic level. Enterprise transformation refers to the change of enterprise in the business philosophy, institutional mechanisms, business models and so on, such as enterprises take the low-cost strategy: improve the labor productivity, reduce production costs. Enterprise transition refers to the enterprise change the development model in the process of innovation and upgrading, but the enterprise still retains the original industry, however, developing and extending in the upstream or downstream of industry chain [7]. Enterprise shift refers to the transformation of the industry, that is, to completely abandon the original development of the industry, then enter into an industry to develop which is not involved in previously [7]. "Others" refers to the strategy besides the implementation of the three, such as: relocate to the convenient transportation, join the Union and so on.

Product innovation ability is the core competitiveness of enterprises which concretely express in the technical level, it is the specific performance of technological innovation and degree of technology intensive. Product function refers to the function or use of the product, the enhancement of product function refers to the product function or use increased, so that we can better meet the needs of consumers [8]. Product added value increases, that is, enterprises enhance product quality and technical content through a series of creative activities, high value-added products can enable to obtain higher profits [8]. New product development cycle is shortened refers to the enterprise technology upgrade, in a shorter period of time, it can create new products. Product diversification refers to the enterprise changes from product a single product to product a variety of products and even form product lines, enterprises can expand market and strengthen the brand influence of enterprises through the product line [8].

Market development ability is the core competitiveness of enterprises which concretely express in the market level, it is a capacity that enterprise find and develop new market. To enter a new 
market refers to the enterprise involved in the original irrelevant market areas. The increasing in the original market share of the enterprise refers to in the original market area, the enterprises attract more consumers, occupy more market share through a series of activities, such as a good impact strategy or to provide more high-quality low-priced products. Enterprise brand influence refers to the formation of enterprises own brand or enterprise own brand is more familiar with the consumer. Way of operation is more efficient means that enterprises through accurate and timely market forecast and analysis, timely changes in marketing strategies, thereby enhancing market competitiveness and gaining profit.

Enterprise management ability is the core competitiveness of enterprises which concretely express in the organizational level. The formation of a unique corporate culture refers to the corporate culture is recognized by the staff and can deeply affect the staff, so that enhance the loyalty of employees to enterprise, and the culture is difficult to be imitated by the rest of the enterprise. The implementation of advanced management means that the implementation of enterprise management innovation or the introduction of advanced management methods, from the original traditional management into information management, from extensive management into fine management, from functional management into process management and so on. Enterprise organization structure is more reasonable refers to the organizational structure of enterprises can be very good to protect the operation of enterprises and support the enterprise innovation and upgrading. Perfect institutional mechanism refers to the enterprise sharing mechanism, incentive mechanism, human resources management mechanism and so on are more perfect, enterprises can choose people, educate people, keep people and use people reasonably, and enterprises' internal information can be shared, all departments can barrier-free communicate.

\section{The Influencing Factors of Enterprise Innovation and Upgrading}

In understanding the content of enterprise innovation and upgrading and after the enterprise innovation and upgrading, enterprise may get change in some areas, then we need to understand the factors which affect the enterprise innovation and upgrading? (See Table 2)

Table 2 The influencing factors of enterprise innovation and upgrading

\begin{tabular}{|c|c|c|c|}
\hline $\begin{array}{l}\text { Level } \\
\text { indicators }\end{array}$ & Secondary indicators & $\begin{array}{l}\text { Level } \\
\text { indicators }\end{array}$ & Secondary indicators \\
\hline \multirow{5}{*}{$\begin{array}{c}\text { Enterprise } \\
\text { external } \\
\text { environment }\end{array}$} & government policy & \multirow{6}{*}{$\begin{array}{c}\text { Enterprise } \\
\text { internal } \\
\text { environment }\end{array}$} & Manager quality \\
\hline & Cooperative & & Human resource situation \\
\hline & Local economy & & company culture \\
\hline & Industry Status & & Sharing mechanism \\
\hline & Location & & Organizational structure \\
\hline \multirow{4}{*}{$\begin{array}{l}\text { Enterprise } \\
\text { dynamic } \\
\text { ability }\end{array}$} & Market perception ability & & Material basis \\
\hline & Resource allocation ability & \multirow{3}{*}{$\begin{array}{c}\text { Level of } \\
\text { technological } \\
\text { innovation }\end{array}$} & Innovation input \\
\hline & Strategic Execution ability & & Innovation output \\
\hline & $\begin{array}{l}\text { Organizational learning } \\
\text { ability }\end{array}$ & & $\begin{array}{l}\text { Innovation incentive } \\
\text { mechanism }\end{array}$ \\
\hline
\end{tabular}

The strength of enterprise innovation and upgrading ability is affected by the external environment of enterprises. The government create an independent innovation environment and give corporate subsidies in order to encourage enterprises to upgrade. The good cooperation within enterprises and other enterprises, research institutions, intermediaries are conducive to enterprise innovation and upgrading. There is a mutually beneficial relationship between the enterprise and the local economy, the good development of the enterprise can create more economic income for the local, and the good local economy in turn to help the enterprise to develop better [9]. Fierce market competition and the ever-changing market demand force enterprises to innovate, and broad market prospects, mature consumer psychology and increasingly standardized market order provide 
protection to innovation and upgrading of enterprises, at the same time, accurately determine the business prospects of the industry can help enterprises plan strategy in advance [9]. Enterprise's traffic is not convenient, information flow will not smooth, if enterprises want to develop sustainablely, we must solve its disadvantages on the geographical position firstly.

Enterprise internal environment is another important factor influencing the innovation and upgrading of the enterprise. The higher the quality of enterprise managers is, the stronger the ability of enterprises innovation and upgrading can be. The higher the level of enterprise staff, the level of knowledge, professional competence and business accomplishment are, the stronger the ability of enterprises innovation and upgrading can be, and the more perfect the incentive mechanism for employees are, the more innovative employees can be. Innovative corporate culture, strong brand awareness and independent intellectual property rights are forcing enterprises to continue to innovate and upgrade. The perfect sharing mechanism within the enterprise, reasonable organizational structure and sufficient material basis is the guarantee and support of enterprise innovation and upgrading.

Enterprise dynamic ability is the ability of enterprises to develop new resources and capabilities. Market perception ability refers to the enterprise market information collection and analysis capabilities, enterprises can accurately and quickly grasp the industry trends, identify market opportunities [10]. Resource allocation ability refers to enterprise can allocate resources timely and reasonably according to the needs of the market and the surrounding environment changes, at the same time, enterprises coordinate departmental relations and adjust the scale of production capacity according to the needs [11]. Strategic execution capability refers to the ability of enterprises to implement the strategy quickly and well after the strategy is developed. Organizational learning ability refers to the ability of enterprises to quickly digest and absorb knowledge.

The level of technological innovation can be seen as the most important factor affecting the innovation and upgrading of enterprises. In general, the innovation of the enterprise is measured by the amount of investment, the number of innovative outputs measured by the number of patents, the incentive mechanism for innovation includes the training of employees and the reward of the innovation of technical personnel. The more innovative the enterprise is, the more perfect the incentive mechanism is, the stronger the innovation ability of the enterprise will be, the more the innovation output will be. The more the innovation output is, the more income will be, which in turn affects the number of innovation input.

\section{The Theoretical Model of the Comprehensive Effect of Enterprise Innovation and Upgrading}

According to the content, performance form and influencing factors of enterprises innovation and upgrading, this paper constructs the theoretical model of the comprehensive effect of enterprises innovation and upgrading. In order to achieve innovation and upgrading, gain sustainable development, enhance the effectiveness of enterprise innovation and upgrading, you can start from the four factors. (See Fig. 1)

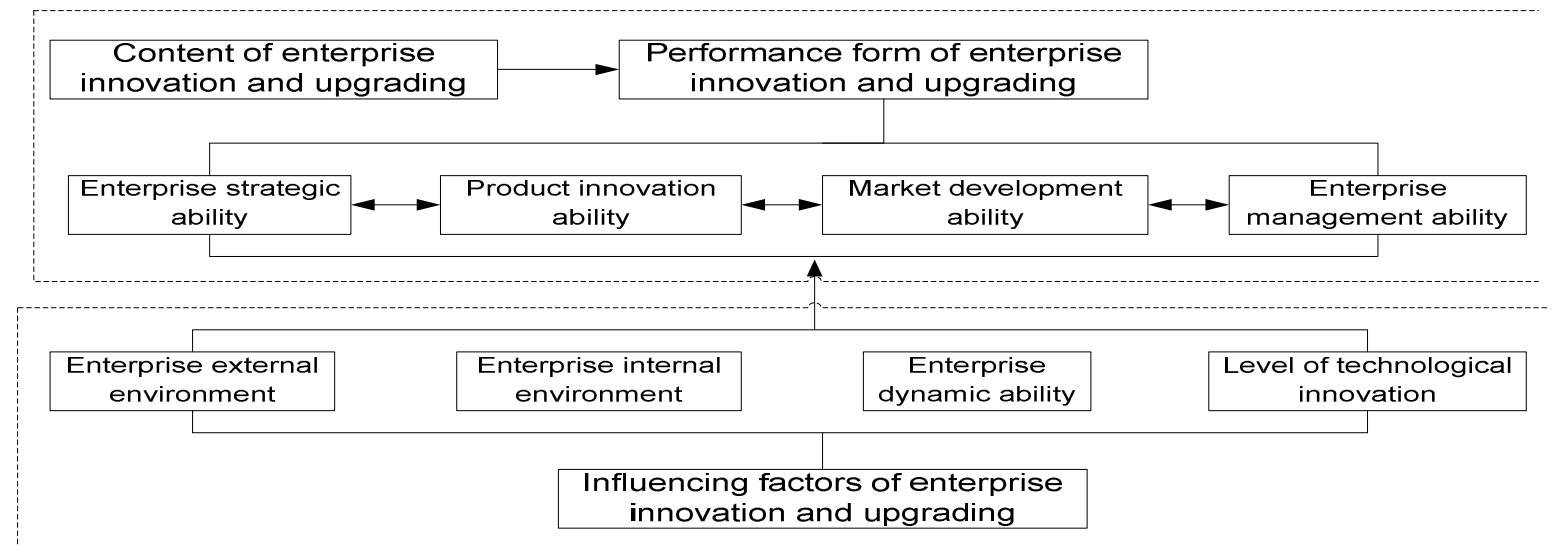

Figure 1. Finite The theoretical model of the comprehensive effect of enterprise innovation and upgrading 


\section{Summary}

The paper defines the concept of enterprise innovation and upgrade on the basis of further study of enterprise innovation, enterprise upgrading, enterprise transformation and upgrading. Then, based on the four performance forms: enterprise strategy ability, product innovation ability, market development ability, enterprise management ability, and based on the four factors: enterprise external environment, enterprise internal environment, enterprise dynamic ability and level of technological innovation, building the theoretical model of the comprehensive effect of enterprise innovation and upgrading, so as to provide theoretical and practical reference for future research.

\section{Acknowledgements}

National Social Science Fund Project(16BGL107); The Fundamental Research Funds for the Central Universities (2017-zy-021).

\section{References}

[1] Xiang Cai. Innovation, Innovative Ethnic Group, Innovation Chain and Its Enlightenment [J] .Research \& Development Management, 2002,14 (6): 35-39.(In Chinese)

[2] Gary Gereffi. International Trade and Industrial Upgrading in the Apparel Commodity Chains [J]. Journal of International Economics, 1999, (43): 37-70.

[3] Humphrey J, Schmitz H. How Does Insertion in Global Value Chains Affect Upgrading in Industrial Clusters [J]. Regional Studies, 2002, 36, (09): 1017-1027.

[4] Shengsheng Chen, Ye Li. Study on the theoretical model of the transformation and upgrading capability of military enterprises [J]. Science and Technology Progress and Countermeasures, 2014,31, (4): 80-83. (In Chinese)

[5] Changwen Zhao, Zhaoyuan $\mathrm{Xu}$. Research on transformation and upgrading of Chinese enterprises since International financial crisis [J]. Management of the world, 2013, (4): 8-15+58. (In Chinese)

[6] Bo Zhang. Research on SMEs' Transformation and Upgrading Strategies [J]. International Conference on Logistics Systems and Intelligent Management, 2012 1: 404-407. (In Chinese)

[7] YeTian He, Zihang Ding. SMEs' transformation model and upgrade path [J]. Modern marketing, 2015, (12): 7-8. (In Chinese)

[8] Yunshi Mao, Yao Wu. Study on the Path and Analysis Mode of Enterprise Upgrade [J].Journal of Sun Yat-sen University (Social Science Edition), 2009,49 (1): 178-186. (In Chinese)

[9] Ye Li, Shihong Wu, Jihui Guo. The influencing factors and path selection of the transformation and upgrading of the third-line military enterprises in the background of military and civilian integration [J]. Science and Technology Progress and Countermeasures, 2015,32, (18): 98-103. (In Chinese)

[10]Lingjie Wei. Research on Upgrade Path of Chinese International Service Outsourcing Enterprise [D]. China Anhui: Anhui University, 2014. (In Chinese)

[11] Ting Ding. Research on Chinese processing trade enterprises's transformation and upgrading [D]. Beijing, China: University of International Business and Economics, 2015. (In Chinese) 